UDC 614.3

DOI: 10.21668/health.risk/2017.3.01.eng

\title{
SANITARY-EPIDEMIOLOGIC SERVICE IN PERM REGION: 95th ANNIVERSARY (DEDICATED TO RUSSIAN SANITARY-EPIDEMIOLOGIC SERVICE)
}

\author{
V.G. Kostarev ${ }^{1}$, V.A. Khoroshavin ${ }^{2}$, A.V. Brazhkin ${ }^{2}$ \\ ${ }^{1}$ Federal Service for Surveillance over Consumer Rights protection and Human Well-being, Perm regional office, \\ 50 Kuybyisheva Str., Perm, 614016, Russian Federation \\ ${ }^{2}$ Center for Hygiene and Epidemiology in Perm region, 50A Kuybyisheva Str., Perm, 614016, Russian Federation
}

The paper outlines the first stages of sanitary activities development in Perm region. We highlight the fact that it was Perm where I.I. Molessson, the first official sanitary inspector in Russia, worked. Here one of the first sanitary inspection of a whole region was performed and "Perm sanitary bulletin" was first published. It was in Perm, where the first sanitary office was established in 1890, and in 1898 the first bacteriological laboratory was organized. Bodies and institutions of Rospotrebnadzor in Perm region are known to be founded on September 15, 1922, when a Decree by Russian People's Commissars Council "On the Republic's sanitary bodies" was issued. A sanitary-hygienic faculty of Perm Medical Institute was set up in 1931 and it gave grounds for preparing qualified sanitary inspectors for state sanitary authorities.

We described basic tasks which were tackled by sanitary inspectors during the Great Patriotic War and just after it. Rospotrebnadzor activities are proved to make for substantial improvements of sanitaryepidemiologic situation in the region. Currently more than $95 \%$ of population are provided with drinking water which fully corresponds to the sanitary legislation requirements. We note constant improvements in catering objects quality and we also see that a quantity of food samples taken at such objects which don't correspond to hygienic standards remains stably low. A share of working places deviating from hygienic standards as per noise, vibration, and illumination, has reduced. Medical examinations are now available to $97.9 \%$ of workers functioning under hazardous (dangerous) working conditions. The lowest occupational morbidity level over the last few years was registered in Perm region in 2016. The Service was among the first in the country to transfer to result-oriented budgeting and risk-oriented surveillance model. Organizational structure is constantly being developed; new legal, economic and organizational approaches are being created and implemented in the activities performed by bodies and institutions of the Federal Service for Surveillance over Consumer Rights protection and Human well-being.

Key words: Sanitary-epidemiologic Service, Perm region, history, achievements.

Attitude towards medicine as a tool of providing "internal security of a state" emerged in the first half of the 19th century [9]. Acknowledgement of new concepts on reasons for epidemics evolvement made the greatest contribution into changes in views on a role which medicine played in life of a state. Epidemics at all times were considered to be one of the most dangerous threats for any state. They caused deaths of thousands and hundreds of thousand people, led to economic instability, did enormous and sometimes even irreparable economic harm [4]. Epidemics were viewed as imminent disasters; however, states did very little to fight them. State interference was mostly limited to fighting already existing epidemics by introducing quarantine

(C) Kostarev V.G., Khoroshavin V.A., Brazhkin A.V., 2017

Vitalii G. Kostarev - Candidate of Medical Sciences, Chief State Sanitary inspector in Perm region, Head of rospotrebnadzor office in Perm region (e-mail: urpn@ 59.rospotrebnadzor.ru; tel.: +7 (342) 239-35-63).

Viktor A. Khoroshavin - Doctor of Medical Sciences, Chief Physician (e-mail: cgepo@mail.ru; tel.: +7 (342) 239-34-09).

Anatolii V.Brazhkin - Doctor of Medical Sciences, Physician (e-mail: brajkin.an@ yandex.ru; tel.: +7 (342) 294-22-71). 
measures which were as cruel as inefficient [2].

And as scientists realized that reasons for epidemics could be cognized and therefore managed (at least partly), it led to working out and implementing a set of activities into a public administration system. Such measures were at first called "medical and police activities" and included:

- introduction of direct public administration of medical activities in the sphere of studying epidemic constitutions, fighting against epidemics and implementation of other national "medical activities on protection and recovery of citizens' health";

- development of specialized medical and sanitary legislation by joint efforts of physicians and lawyers;

- fighting against quacks and provision of population with highly qualified medical personnel via radical reforms in the sphere of medical education;

- creation of a state system for providing assistance to people in need and socially insecure population groups (orphans, elderly and disabled people, lowincome families, beggars, etc.);

- implementation of specific activities aimed at creating healthy lifestyle, providing healthy nutrition and safe working conditions.

Each of the above-mentioned activity spheres became a true innovation not only in the history of medicine, but also in the public administration history.

A concept of creating permanently functioning organizations - prototypes of a sanitary service - started to be put into practice in the second half of the 19th century [9]. It was related to the foundation of zemstvo (a regional administration) in 34 provinces of the Russian Empire in 1864. Medicine in a zemstvo should be headed by a physician who could introduce pre- ventive measures protecting wide layers of population (Photo 1). Preventive approach was completely in line with ideas of great N.N.Pirogov who said, "I believe in hygiene. It is there where a true progress of our science lies. Future belongs to preventive medicine" [7].

Perm region can take great pride in the fact that Ivan Ivanovich Molesson (1842-1920), one of our citizens, became the first sanitary inspector in Russia and started his career in our region (Permskaya province back then) (Photo 2). He arrived in Perm in 1871 to work as a doctor in the main province hospital and he was the first to suggest a sanitary examination of the province [1]. In 1874 cattle plague epizooty caused death of practically all cattle in Perm. To fight this dangerous infection, first a sanitary committee was created and later on a permanent sanitary commission was established to "deal with issues related to the city hygiene". In 1886 Molesson introduced the first issue of "Perm epidemiologic bulletin". And it was in Perm in 1890 when the first sanitary office was created and in 1898 the first bacteriological laboratory was set up ${ }^{1}[1,5]$.



Photo 1. Doctors from zemstvo examining patients in Kazan

${ }^{1}$ In 1912 it was re-organized into a scientific and research institute (now it is "Biomed" scientific and production association). 


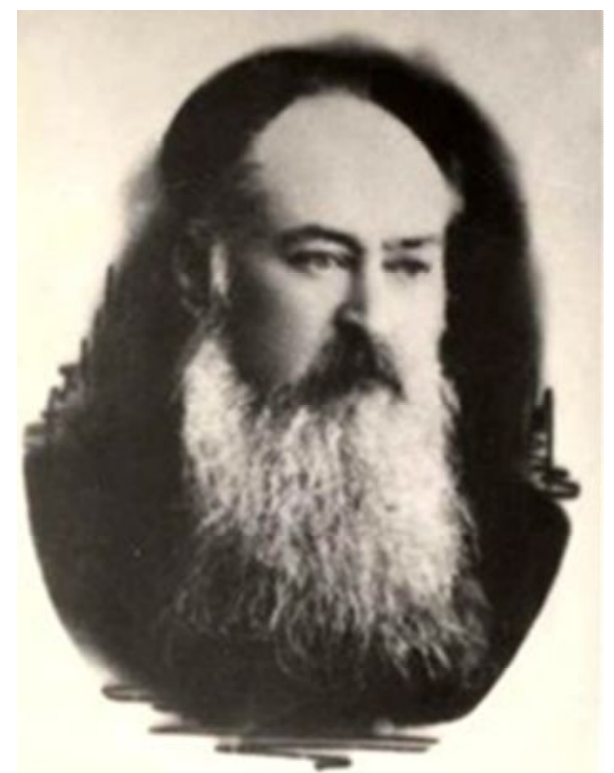

Photo 2. I.I. Molesson (1842-1920)

In July 1918 the RSFSR People's Commissariat for Public Health was established and a sanitary-epidemiologic section was a part of it; and in 1920 a sanitary department of Perm regional public healthcare office was organized; its main task was to implement sanitaryepidemiologic activities on the territory of Perm region.

Offices and bodies of Rospotrebnadzor Perm regional office can trace their history back to September 15, 1922, when a Decree "On the Republic sanitary bodies" was signed by the RSFSR People's Commissariat. In 1926 a sanitary and hygienic laboratory headed by K.N. Shapshnev, a professor form the Perm State University, was opened in the city; in 1934 the laboratory was named after him [8].

The first law "On the Republic sanitary bodies" was passed by the RSFSR People's Commissariat on February 1927; and the regulations on them were adopted on October 8, 1927. According to them, sanitary organs received wider functions and rights; they also fixed differentiated standards for providing regions and cities with sanitary personnel, bacteriological la- boratories, and disinfection stations, depending on their industrial significance. Preventive sanitary surveillance at all stages of industrial and civil construction became the most important part in the RF sanitary bodies functioning. In August 1929 the RSFSR People's Commissariat listened to the report "On sanitary state in the Republic".

In 1931 a sanitary-hygienic faculty was created in the structure of Perm Medical Institute and it gave grounds for providing state sanitary and epidemic service offices with highly qualified sanitary inspectors. You can see a team of Molotov city sanitary inspection in Photo 3 (1936).

During the Great Patriotic War the sanitary service had peculiar tasks to perform [10]. Epidemic typhus morbidity grew drastically in Perm (Molotov back then) in November-December 1941, and an issue of fighting back pediculosis became truly vital for public healthcare organs and institutions. 5th grade students of the medical institution were assigned to accomplish the task and they did a great job preventing epidemic typhus spread in the city and the region as a whole.

The Regional sanitary and Epidemiologic station was established on April 23, 1942 by a decree passed by Molotov regional deputies council. Later on, in the 50ties last century 41 sanitaryepidemiologic stations and 32 sanitarybacteriological laboratories were founded all over the region.

70-80ties last century were the period in Perm regional sanitary and epidemiologic service functioning when complex work with enterprises, institutions, and organizations was accomplished in the sphere of health protection, improving working conditions, and lowering workers' morbidity. To fulfill the set tasks, complex plans of sanitary-epidemiologic activities 
were created and implemented; such plans were approved by sessions of city and district People's Deputies Councils.

A new RSFSR law "On sanitary and epidemiologic welfare of the population" was passed in 1991 and it opened a new chapter in sanitary-epidemiologic service development. All district and city sanitary and epidemiologic stations ceased to be subordinated to Public Healthcare administrations and were given into subordination to Regional Sanitary-Epidemiologic Service by the Decree of Perm regional executive council No.215 issued on September 12, 1991, and by the Order of Regional Public Healthcare Administration and Regional Sanitary-Epidemiologic Service No. 398/134 issued on September 18, 1991. Overall, 47 offices of the State SanitaryEpidemiologic Service carried out state sanitary and epidemiologic surveillance in the region.

At the same time laboratory base was equipped with modernized devices and tools and it allowed to substantially enlarge laboratories' capabilities, to increase labor- atory research validity, and to make laboratory examinations quite shorter.

Over these years a lot of outstanding state sanitary and epidemiologic service officials and scientists worked in Perm region: B.I. Raikher, A.V. Pshenichnov, V.V. Dianova, V.F. Petrov, G.V. Shaklein, T.M. Lebedeva, M.L. Krasovitskaya, N.V. Zaitseva, N.M. Koza, I.V.Feldblum, A.Ya. Perevalov. Some of them were Chief State Sanitary Inspectors in Perm region, honored scientists, State Prize winners, honored physicians of the USSR and the RF, Doctors and Candidates of Science.

E.N. Belyaev, an outstanding organizer and supervisor, was the head of the Regional Sanitary-Epidemiologic station from 1975 to 1986. Later Evgeniy Nikolaevich was the head of the Central sanitary-epidemiologic administration of the RSFSR Public Healthcare Ministry and the head of the State Committee of the RSFSR sanitary-epidemiologic surveillance.

In the early 90ties Perm regional sanitary and epidemiologic service was one of the first to introduce a new economic mechanism.

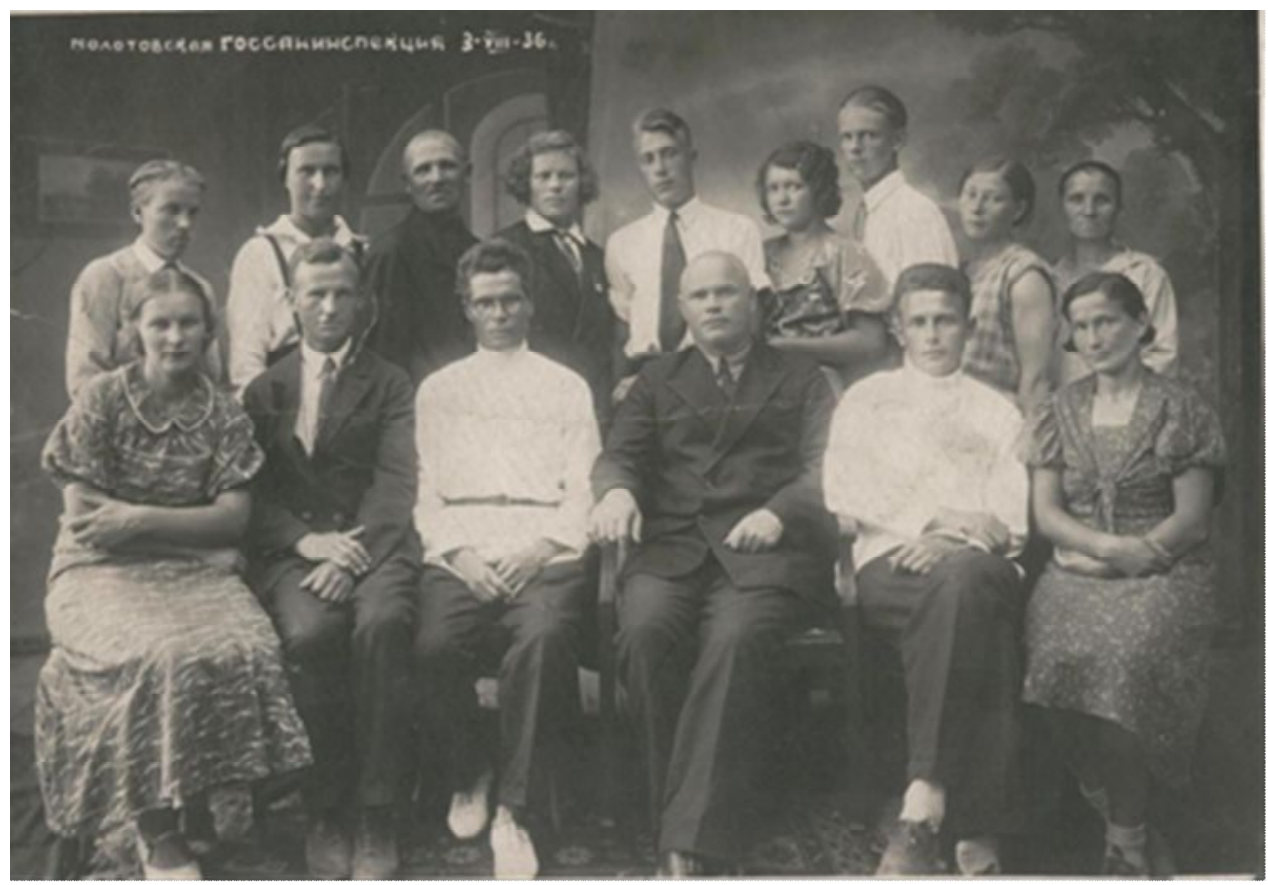

Photo 3. Team of Molotov city sanitary inspection, August 1936. 
It was at the initial stage of reforms when basic activities of Perm regional sanitary and epidemiologic service activities were optimized; these activities were related to water supply and sewerage in settlements, surveillance over working conditions, food products storage and trade conditions, and organization of educational process.

Later on, State sanitary and epidemiologic service was taking active part in licensing and certification of specific works and services, as well as products which could be potentially dangerous for human health. It carried out radiation control on the region territory and developed a new activity - social and hygienic monitoring which was aimed at assessing population health and environment, at detecting changes in them and predicting their state.

Over those years the organizational structure of the service was continuously reorganized; new departments were created to examine population health in relation to impacts exerted by environmental factors, to introduce automated control systems, to accomplish hygienic certification of laboratories, to perform metrological tasks, etc. Perm Scientific and Research Institute for Children Ecological Pathology headed by the academician N.V. Zaitseva took part in new activities devoted to assessing population health risks caused by environmental factors.

Over the following years the service went on searching for new organizational forms of activity as centralization of administration and funding was widely introduced. In 2002-2003 The Program for Transformation of the Perm regional state sanitary and epidemiologic service organizational structure was successfully implemented. 18 inter-district state sanitary and epidemiologic surveillance centers were created in the region instead of former 47 ones; they fully concentrated staff and material and technical resources, and laboratories were also centralized and consolidated.

Reforms allowed to split surveillance functions from other which didn't belong to a state authority; quality of sanitary and epidemiologic surveillance increased, and funds from the Federal budget were now spent more efficiently.

Foundation of the Federal Service for Surveillance over Consumer Rights Protection and Human Well-being in conformity with the Order by the RF President issued on March 9, 2004 No. 314 "On the system and structure of the Federal Executive Bodies" became a new milestone in organizational and legal construction of the state sanitary service. Perm Regional Office of the Federal Service for Surveillance over Consumer Rights Protection and $\mathrm{Hu}-$ man Well-being was established in Perm region; it comprised 4 territorial departments and Center for Hygiene and Epidemiology in Perm Region and KomiPermyatskiy autonomous district and its 9 subsidiaries. Their main tasks were to accomplish state surveillance and control over compliance with the RF legislation in the sphere of providing sanitary and epidemiologic welfare of the population and consumer rights protection; to prevent hazardous impacts exerted on people by environmental factors; to prevent infectious and non-infectious diseases (intoxications) of the population. Center for Hygiene and Epidemiology in Perm Region and KomiPermyatskiy autonomous district provided activities of the surveillance territorial body of the Federal Service for Surveillance over Consumer Rights Protection and Human Well-being.

When a new RF region - Permskiy krai - was created on December 12, 2005, bodies and organizations of the Federal Service for Surveillance over Consumer 
Rights Protection and Human Well-being in Perm regions were Perm Regional Rospotrebnadzor Office, its 6 territorial departments, Center for Hygiene and Epidemiology in Perm Region and its 6 subsidiaries, and Federal Scientific Center for Medical and Preventive Health Risk Management Technologies which was created by the RF Government decision No. 628 taken on May 8, 2009 on the basis of the Perm Scientific Research Clinical Institute for Children Ecological pathology. The said Center is a truly leading organization of the RF Rospotrebnadzor which has made a substantial contribution into the methodology of state sanitary epidemiologic service optimization, worked out and implemented a risk-oriented approach to surveillance activity, created a number of organizational-administrative, regulative, and methodical documents applied in the activities of the Federal Service for Surveillance over Consumer Rights Protection and Human Well-being.

Today, more than 1,000 highly qualified experts work in Rospotrebnadzor bodies and organizations in Perm region; among them there are honored public healthcare workers, people with honorary diplomas granted by the RF Public Healthcare Ministry, Doctors and Candidates of Medical Sciences.

Activities of the sanitary service are quite efficient. Today a share of Perm region population provided with drinking water which conforms to the sanitary legislation requirements amounts to $95.5 \%$. A number of people living within sanitaryhygienic zones of enterprises tends to decrease. Catering objects quality is constantly growing and a number of food samples not conforming to standards remains low ( $1 \%$ over the last years). Over the last years there have been no positive samples of genetically modified products registered in the region [6].

There also have been no mass noninfectious intoxications of population in the region related to consumption of lowquality and dangerous food products. Since 2013, population morbidity related to micronutrient deficiency has leveled off. Over the last 5 years a number of intoxications with alcoholic products has decreased by more than $25 \%$.



Photo 4. Legal consultations on issues related to drugs traffic in Perm region In the foreground - V.G. Kostarev, Head of Rospotrebnadzor office in Perm region 
A set of organizational and surveillance activities in the sphere of providing sanitary and epidemiologic welfare of the regional population made for decrease from $19 \%$ to $15 \%$ in the number of preschool children facilities with overcrowded groups; a share of working places with artificial luminance not conforming to standards decreased to $7 \%$ in comparison with the previous year; with furniture not conforming to standards, to $13 \%$. $90 \%$ of school children were provided with high quality nutrition in 2016.

Permanent contacts between the Service and civil society representatives as well as with other administrative bodies are constantly growing; it concerns especially such vital issues as drugs addiction and distribution (Photo 4). Rospotrbnadzor Perm regional office is to implement state policy in this sphere and to make dishonest entrepreneurs and juridical persons to bear responsibility for their products and services' quality. Functions of the State surveillance organization are equally aimed at compliance with hygienic standards both for children and adults, as well as at sanitary and epidemiologic surveillance.

To detect violations in other spheres, the service accomplishes inspections together with other surveillance bodies (Federal Agency of technical Regulating and Metrology, EMERCOM of Russia, Federal Tax Service, etc.)

Due to task-oriented interdepartmental interaction by public administrative bodies, surveillance and control authorities, and employers in 2014-2016 we managed to achieve positive results in providing sanitary-epidemiologic welfare at industrial objects, in communal sphere, in education, and in public healthcare.

A share of working places not conforming to hygienic standards as per noise, vibration, and luminance parameters, has decreased. $97.9 \%$ workers employed at hazardous (dangerous) productions had their medical examinations. In 2016 registered occupational morbidity in the region dropped to the lowest level over the last years.

Under massive administrative and budget reforming which state control and surveillance authorities had to undergo, Perm regional sanitary and epidemiologic service managed not only to preserve its authority but also to substantially enlarge its capabilities. Perm experts took a most active part in creating methodological grounds for organization and functioning of the Service under result-oriented budgeting, program-targeted planning, transfer to subsidiary budgeting and risk-oriented control (surveillance).

A history of Perm regional sanitary and epidemiologic service creation and development is not coming to its end today as new solid grounds for future are being formed. To achieve it, organizational structure is being improved, new legal, economic, and organizational approaches in the activities of bodies and organizations of the Federal Service for Surveillance over Consumer Rights Protection and Human Wellbeing are being created and implemented.

Each expert who works in the Service today is fully aware of the responsibility he or she bears; after all they are to protect health and welfare of all the people living in Perm region!

\section{References}

1. Vullo I.I. Stranichka iz zhizni pervogo sanitarnogo vracha Rossii I.I. Mollesona: (K 125letiyu so dnya rozhdeniya) [Some moments from the life of I.I. Molleson, the first Russian sanitary inspector: (dedicated to his 125th anniversary]. Gigiena i sanitariya, 1966, no. 9, pp. 50-53 (in Russian). 
2. Geling K. Opyt grazhdanskoi meditsinskoi politsii, primenennyi k zakonam Rossiiskoi imperii [Experience of civil medical police applied in the Russian Empire legislation]. Vil'na, 1842, vol. 1, 631 p. (in Russian).

3. Igumnov S. Ivan Ivanovich Molleson. Russkii vrach, 1911, vol. X, no. 30, pp. 1220 (in Russian).

4. Meier-Shteineg T., Zudgof K. Istoriya meditsiny [History of medicine]. In: V.A. Lyubarskii, B.E. Gershuni, eds. Moscow, Gosizdat, Publ., 1925, 463 p. (in Russian).

5. Nazarov V.V. Pervyi sanitarnyi vrach Rossii (o saratovskom periode deyatel'nosti Ivana Ivanovicha Mollesona) [First Russian sanitary inspector (on Ivan Ivanovich Molleson activities in Saratov)]. Saratovskii kraevedcheskii sbornik: Nauchnye trudy i publikatsii. Saratov, 2002, issue 1, pp. 167-171 (in Russian).

6. O sostoyaniisanitarno-epidemiologicheskogo blagopoluchiya naseleniya $\mathrm{v}$ Permskom krae v 2016 godu: Gosudarstvennyi doklad [On sanitary-epidemiologic welfare of the population in Perm region in 2016: State report. Perm': Upravlenie Rospotrebnadzora po Permskomu krayu, FBUZ «Tsentr gigieny I epidemiologii v Permskom krae», 2017, 266 p. (in Russian).

7. Pirogov N.I. Sevastopol'skie pis'ma I vospominaniya [Letters and memories from Sevastopol]. Moscow, Izd. Akademii nauk SSSR, Publ., 1950, 652 p. (in Russian).

8. Razvitie zdravookhraneniya v Permskoi oblasti: material v pomoshch' lektoru [Development of public healthcare in Perm region: materials to help a lecturer] compiled by V.T. Selezneva. Perm', 1987, pp. 30-46 (in Russian).

9. Stochik A.M., Zatravkin S.N., Stochik A.A. Stanovlenie gosudarstvennoi meditsiny (vtoraya polovina XVIII - pervaya polovina XIX veka). Soobshchenie 1. Vozniknovenie kontseptsii meditsinskoi politsii, organov upravleniya mediko-sanitarnym delom, vrechebnosanitarnogo zakonodatel'stva [The becoming of public medicine (second half of XVIII-first half of XIX centuries). Report 1: The origin of concept of medical police, governing bodies of medical sanitary business, physician sanitary legislation]. Problemy sotsial'noi gigieny, zdravookhraneniya $i$ istorii meditsiny, 2013, no. 1, pp. 44-49 (in Russian).

10. Khoroshavin V.A., Akimova L.N., Shutova O.V. Sanitarno-epidemiologicheskaya sluzhba v Permskoi oblasti v gody Velikoi Otechestvennoi voiny [Sanitary services in the perm region during the Great Patriotic war]. Health Risk Analysis, 2015, no. 2, pp. 89-94. DOI: 10.21668/health.risk/2015.2.11.eng. (in Russian).

Kostarev V.G., Khoroshavin V.A., Brazhkin A.V. Sanitary-epidemiologic service in Perm region: 95th anniversary (dedicated to Russian sanitary-epidemiologic service). Health risk analysis, 2017, no. 3, pp. 4-11. DOI: 10.21668/health.risk/2017.3.01.eng

Received: 11.06 .2017

Accepted: 16.09.2017

Published: 30.09.2017 